\title{
Effect of different levels of single super phosphate on growth and yield of rose grown in soil media under polyhouse condition
}

\section{H.B. KALBHOR, D.E. PATIL AND A.V.PATIL}

MEMBERS OF RESEARCH FORUM:

Corresponding author :

A.V. PATIL, Division of Soil Science and Agricultural Chemistry, College of Agriculture, PUNE (M.S.) INDIA Email: avpssac@gmail.com

Co-authors :

H.B. KALBHOR AND D.E. PATIL,

Division of Soil Science and

Agricultural Chemistry, College of

Agriculture, PUNE (M.S.) INDIA
Received : 19.10.2015; Revised : 09.11.2015; Accepted : 24.11.2015

\section{Summary}

An investigation was carried out to study the effect of different levels of single super phosphate on growth and yield of rose grown in soil media under polyhouse conditions. The treatments comprised of application of two levels and two methods of single super phosphate with application of monocalcium phosphate as a control treatment. The application of $18 \mathrm{~g}$ single super phosphate in two equal splits (basal and 50 days after planting) significantly increased growth with respect to number of leaves (32.5 per plant), number of branches (3.75 per plant), plant height $(49.7 \mathrm{~cm})$, number of flowers (3.75 per plant) and least number of days required for flowering (8.56) from bud initiation. Significantly higher yield of rose and nutrient uptake was observed in the same treatment. The significant increase in fresh and dry weight of flower (24.98, 5.5. g, respectively) were reported in same treatment. The treatment of $18 \mathrm{~g}$ single super phosphate in two equal splits also recorded significantly higher total uptake of macro and micronutrients by rose over other treatments of single super phosphate and monoammonium phosphate (Control).

Key words : Single super phosphate, Growth, Yield, Rose, Soil, Polyhouse

How to cite this article : Kalbhor, H.B., Patil, D.E. and Patil, A.V. (2015). Effect of different levels of single super phosphate on growth and yield of rose grown in soil media under polyhouse condition. Asian J. Soil Sci., 10(2) : 283-287. 